\title{
Analysis of deposit savings in Islamic and conventional banks
}

\author{
Putri Jamilah*; Jaka Sriyana \\ Faculty of Economics, Universitas Islam Indonesia, Yogyakarta, Indonesia \\ *To whom correspondence should be addressed. Email: putrijamilah61@yahoo.co.id
}

\begin{abstract}
Indonesia is a country that implements a dual banking system. The progress of the conventional financial industry coincides with the development of the Islamic financial sector. This study discusses the influence of external factors namely inflation, broad money (M2), BI rate and internal factors namely return on asset (ROA) and operational efficiency ratio (OER) on profit-sharing of Islamic banking deposits and conventional banking deposits interest. The method used in this study was the Error Correction Model (ECM). Based on the results of the study, it can be concluded that inflation and broad money (M2) affects the profit-sharing of deposits. Whereas the conventional bank deposit interest is influenced by ROA, OER, BI rate, inflation, and M2. The fluctuation of external and internal variables has an impact on Islamic banks and conventional banks in determining interest and profit-sharing of deposits.
\end{abstract}

Keywords: ROA, OER, BI rate, inflation, broad money, deposits, profit sharing

JEL Classification: G21, E51, E43

\section{INTRODUCTION}

Banks have an important role in fostering the economic growth of a country. All business sectors, including industry, trade, agriculture, plantation, services, housing, and so on, are in desperate need of banks as partners in developing their businesses (Ismail, 2011). However, the fall of the Indonesian banking industry in 1998, the lack of liquidity and the loss of public confidence in the banking sector resulted in a negative balance on the clearing accounts of these banks by the central bank of the Republic of Indonesia (Bank Indonesia/BI). Many people withdrew their money from their savings and caused these banks to have liquidity problems. To anticipate these conditions, the government provided liquidity assistance to banks experiencing liquidity issues and guaranteeing programs to the people's deposits.

Islamic commercial banks and conventional banks that opened sharia branches are developing. It was supported by the persistence of Islamic banks at a time where there was a severe crisis in the banking industry in 1998. The sharia banking system in the form of profit-sharing at the Muamalat Bank caused the bank to survive influence the soaring deposit rates so that operational costs are lower than conventional banks (Subekti, 2004).

The impact of the economic turmoil in 1998 is that the macro-economy was very influential on the development of the banking industry. Monetary policy is an integral part of the macroeconomic policy. Monetary policy is therefore created to support the achievement of macroeconomic objectives. As the monetary authority, Bank Indonesia had the task of regulating the funds allocated to circulate money and influencing the interest rate in such a way as to meet macro policy objectives (Iswardono, 1994). 
Islamic banks can be considered as one financial industry. It has different markets for its main activities than conventional banking. This paper will look at the influence of economic growth, inflation, the money supply (M2), and the BI rate on Indonesia's banking development.

\section{THEORETICAL FRAMEWORK}

\section{Influence of inflation on deposits interest and profit-sharing of deposits}

High inflation is an economic problem, causing purchasing power (income) falls. People who have fixed income will continue to be harmed while those who do not have regular income sometimes get benefit from it. Thus, inflation can affect income distribution. Inflation is the connecting variable between the interest rate and the effective exchange rate, where both of these variables are important in determining growth in the production sector (Sukirno, 2011).

Sriyana (1995) stated that inflation is the most important factor causing a high level of public expenditure. So, if public expenditure increases without being balanced by the increasing income, the people's buying power will decrease. The government may need to control the inflation rate in the public interest.

H1: inflation has a negative effect on deposits interest and profit-sharing of deposits.

\section{The influence of the broad money on deposits interest and profit-sharing of deposits}

The money supply is a relatively new subject of study compared to the money demand. This condition was caused by the assumption that the central bank could directly determine the money supply so that other external factors could not influence it (Iswardono, 1999).

Antoni (2015) showed that all aggregate finance (narrow and broad money) was claiming positive trends. The financial sector fostered economic growth and the right interest rate was used as a basis for policymaking.

H2: the broad money has a negative effect on deposits interest and profit-sharing of deposits.

\section{The influence of the BI rate on deposits interest and profit-sharing of deposits}

The BI rate is an interest rate policy that reflects the monetary policy stance set by Bank Indonesia, the central bank of the Republic of Indonesia, and is announced to the public (www.bi.go.id). Board of Governors holds meetings every month and the policy is implemented by Indonesian banks through liquidity management on the money market to meet operational objectives of monetary policy. The operational objectives of monetary policy are reflected in the development of overnight interbank money market interest rate (PUAB o/n / Pasar Uang Antar Bank overnight). This movement in PUAB rates is expected to be followed by developments in deposit rates and in turn bank lending rates.

According to Andrianus (2006), interest rates influenced individual decisions about choosing to spend more money or save money in the form of savings. The interest rate itself is a price connecting the present with the future.

H3: BI rate has a positive effect on deposits interest and profit-sharing of deposits.

\section{Effect of ROA on deposits interest and profit-sharing of deposits}

The ratio is used to measure the ability of a bank's management to gain profit as a whole. The greater the ROA of a bank, the greater the bank's level of profit, and the better the position of the bank in terms of asset use. The ratio is as follows (Dendawijaya, 2001):

$$
\mathrm{ROA}=\frac{\text { net profit }}{\text { total assets }} \times 100 \%
$$


Arif (2014) stated that profitability ratios are measured by ROA. It means that if the bank has a high level of profitability, it will increase third-party funds. ROA is one of the large funds' determinants that will be deposited in Islamic banks.

H4: ROA has a positive effect on deposits interest and profit-sharing deposits.

\section{Influence of OER on deposits interest and profit-sharing of deposits}

According to Bank Indonesia (BI), operational efficiency ratio (OER) is used to measure the effectiveness of provisions. BI has determined that the OER's best rate is below $90 \%$. If the OER ratio exceeds $90 \%$ to nearly $100 \%$, it means that the bank is inefficient in carrying out its operations. Bank Indonesia Circular Letter No. 6/23/DPNP (2004) was formulating OER calculation as follows:

$$
\text { OER }=\frac{\text { total operational cost }}{\text { operational income }} \times 100 \%
$$

According to Arif (2014), the higher the level of OER, the more inefficient the bank is in the operational cost, which means that the cost is greater than income from operations. This could be due to the fact that bank efficiency is a determinant of the customer's decision.

H5: OER has a negative effect on deposit interest and deposits profit-sharing.

\section{RESEARCH METHODS}

The objects of the study were Islamic banks and conventional banks in Indonesia. Data from Islamic banks and conventional banks were collected by the researcher and the data itself have been published by Bank Indonesia (BI), the Financial Services Authority (OJK), and the Central Statistics Agency (BPS).

The variables used in this study were return on asset, operational efficiency ratio, $\mathrm{BI}$ rate, inflation, and broad money (M2).

The data used are time series data for the period of $2008-2017$. The method used for analyzing data was the Error Correction Model (ECM):

Islamic bank ECM model:

$$
\begin{aligned}
\Delta D P S \_S_{t} & =\alpha_{1}+\beta_{1}\left(e_{t-1}\right)+\sum_{i=0}^{m} \alpha_{1, \mathrm{i}}, \Delta I R_{t-1}+\sum_{i=0}^{m} \mathbf{b}_{1, \mathrm{i}}, \Delta M 2_{t-1} \\
& +\sum_{i=0}^{m} \mathrm{C}_{1, \mathrm{i}}, \Delta I N F_{t-1}+\sum_{i=0}^{m} \mathrm{~d}_{1, \mathrm{i}}, \Delta R O A_{t-1}+\sum_{i=0}^{m} \mathbf{e}_{1, \mathrm{i}}, \Delta O E R_{t-1}+\varepsilon_{1 t}
\end{aligned}
$$

Conventional bank ECM model:

$$
\begin{aligned}
\Delta D I \_K_{t} & =\alpha_{1}+\beta_{1}\left(e_{t-1}\right)+\sum_{i=0}^{m} \alpha_{1, i}, \Delta I R_{t-1}+\sum_{i=0}^{m} b_{1, i}, \Delta M 2_{t-1} \\
& +\sum_{i=0}^{m} \mathbf{C}_{1, i}, \Delta I N F_{t-1}+\sum_{i=0}^{m} d_{1, i} \Delta R O A_{t-1}+\sum_{i=0}^{m} e_{1, i}, \Delta O E R_{t-1}+\varepsilon_{1 t}
\end{aligned}
$$

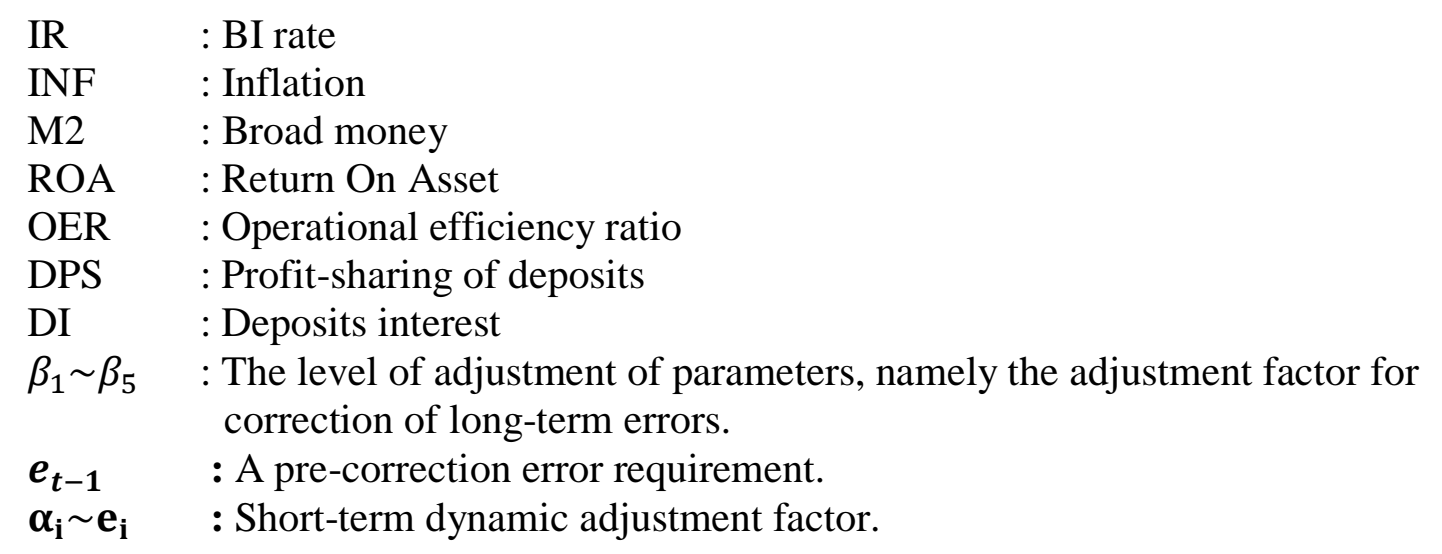


$\begin{array}{ll}\boldsymbol{m} & : \text { Lag period for all variables } \\ \boldsymbol{\varepsilon}_{1 \boldsymbol{t}} \sim \boldsymbol{\varepsilon}_{\mathbf{5 t}} & : \text { White noise. }\end{array}$

\section{RESULT AND DISCUSSION}

Error Correction Model (ECM) is used as an econometrics tool calculation and descriptive analysis method aims to find the long-term and short-term effects resulting from the co-integration of variables. Before the estimation process, several steps must be carried out as follows:

\section{Stationarity test}

In order to obtain a stationarized data at the level of conventional banks and Islamic banks, namely the BI rate and OER, first difference test was conducted. It was due to some variables are not stationary. The result showed that the on the more negative variable from the critical point value of $5 \%$ and the $\mathrm{p}$-value had a value smaller than 0.05 , so $H_{0}$ was rejected. It can be concluded that the data were stationary (no root unit).

\section{Co-integration}

Co-integration test then was performed to find out whether there was a long-term relationship between the variables used in this study. The following tables are presented as co-integration results of the data used in this research using the Residual Based Test Method.

Table 1. Conventional bank co-integration test

\begin{tabular}{llll}
\hline \multicolumn{2}{l}{ Phillips-Perron Statistic Test } & Adj. t-Stat & Prob.* \\
\cline { 2 - 3 } & & -5.330976 & -3.486064 \\
\hline \multirow{2}{*}{ Test critical values } & $1 \%$ level & -2.885863 & -0000 \\
\cline { 2 - 3 } & $5 \%$ level & -2.579818 \\
\cline { 2 - 3 } & $10 \%$ level &
\end{tabular}

Table 2. Islamic bank co-integration test

\begin{tabular}{llll}
\hline \multicolumn{2}{l}{ Phillips-Perron Statistic Test } & Adj. t-Stat & Prob.* \\
\cline { 2 - 3 } \multicolumn{2}{l}{ Test critical values } & & -8.091148 \\
& $1 \%$ level & -3.486064 & -0000 \\
\cline { 2 - 3 } & $5 \%$ level & -2.885863 & -2.579818 \\
\cline { 2 - 3 } & $10 \%$ level &
\end{tabular}

From Table 1 and Table 2, they were known significantly to co-integration over the long-term and short-term. It could be seen from the significance of the probability value that was smaller than test critical value $1 \%, 5 \%$, and $10 \%$. Moreover, t-statistic value was greater than Mackonnion Critical Value so that data was co-integrated.

\section{Error Correction Model (ECM) test}

The Table 3 shown by the model explained that it has a long-term and short-term relationship. Both in the long-term and short-term, ROA does not have a significant effect on the deposits interest of conventional banks. It can be seen from the probability value of ROA, in the long-term of 0.9427 and the short-term of 0.1401 .

Both in the long-term and short-term, OER has a significant effect on the deposit interest of conventional Banks. This can be seen from the probability value of ROA, in the long-term of 0.0070 and the short-term of 0.000 . In the long-term, OER has a positive effect, but in the short-term, OER has a negative effect on the deposit interest of conventional banks. 
Table 3. ECM estimation results on conventional banks

\begin{tabular}{|c|c|c|c|c|}
\hline Variable & Coefficient & Std. Error & t-Statistic & Prob. \\
\hline \multicolumn{5}{|c|}{ Long-term } \\
\hline $\mathrm{C}$ & 103725.2 & 53414.58 & 1.941889 & 0.0546 \\
\hline ROA & 9.563573 & 132.6653 & 0.072088 & 0.9427 \\
\hline OER & -1475.125 & 537.1844 & -2.746031 & $0.0070 * * *$ \\
\hline INF & 8832.552 & 4157.057 & 2.124712 & $0.0358 * *$ \\
\hline IR & 0.012018 & 0.003213 & 3.740061 & $0.0003 * * *$ \\
\hline M2 & -514697.2 & 195912.6 & -2.627178 & $0.0098 * * *$ \\
\hline \multicolumn{5}{|c|}{ Short-term } \\
\hline $\mathrm{C}$ & 1151.341 & 1970.670 & 0.584239 & 0.5602 \\
\hline $\mathrm{D}(\mathrm{ROA})$ & 345.4523 & 232.4717 & 1.485997 & 0.1401 \\
\hline $\mathrm{D}(\mathrm{OER})$ & -2265.611 & 531.3309 & -4.264030 & $0.0000 * * *$ \\
\hline $\mathrm{D}(\mathrm{INF})$ & 3270.102 & 10652.98 & 0.306966 & 0.7594 \\
\hline $\mathrm{D}(\mathrm{IR})$ & -378008.2 & 286667.8 & -1.318628 & 0.1900 \\
\hline D(M2) & -0.012826 & 0.003902 & -3.286719 & $0.0014 * * *$ \\
\hline RES(-1) & -0.326343 & 0.068594 & -4.757621 & 0.0000 \\
\hline
\end{tabular}

$* * * \alpha 1 \% ; * * \alpha 5 \% ; * \alpha 10 \%$

In the long-term, INF has a significant positive effect, but in the short term, INF does not have a significant effect on the conventional bank deposit interest rates. This can be seen from the probability value of INF, in the long-term of 0.0358 and the short-term of 0.7594

In the long-term, IR has a significant positive effect, but in the short-term, IR does not have a significant effect on the conventional bank deposits interest rates. This can be seen from the probability value of IR, in the long-term of 0.0003 and the short-term of 0.1900 .

Both in the long and short-term, M2 has a significant negative effect on the deposit interest of conventional Banks. This can be seen from the probability value of M2, in the long-term of 0.0098 and the short-term of 0.0014 .

Table 4. Results of ECM estimates on Islamic banks

\begin{tabular}{lrrrr}
\hline Variable & Coefficient & Std. Error & t-Statistic & Prob. \\
\hline C & Long-term & & & \\
ROA & -28340.66 & 36985.22 & -0.766270 & 0.4451 \\
OER & -1983.668 & 5309.466 & -0.373610 & 0.7094 \\
IR & 37.11357 & 326.9243 & 0.113523 & 0.9098 \\
INF & -3161.872 & 2890.163 & -1.094012 & 0.2763 \\
M2 & 139405.0 & 137850.2 & 1.011279 & 0.3140 \\
\hline \multicolumn{1}{c}{} & 0.038531 & 0.003003 & 12.83278 & $0.0000^{*}$ \\
\hline D(ROA) & Short-term & & & \\
D(OER) & 1665.865 & 538.5112 & 3.093464 & 0.0025 \\
D(INF) & 434.7713 & 2349.658 & 0.185036 & 0.8535 \\
D(IR) & -54.47244 & 83.48005 & -0.652520 & 0.5154 \\
D(M2) & 1578.644 & 2854.441 & 0.553048 & 0.5813 \\
RES(-1) & 29401.78 & 60578.89 & 0.485347 & 0.6284 \\
& -0.002103 & 0.001236 & -1.701793 & $0.0916^{*}$ \\
& -0.125705 & 0.033720 & -3.727914 & 0.0003 \\
\hline
\end{tabular}

$*_{\alpha} 1 \% ; * * \alpha 5 \% ; * * * \alpha 10 \%$ 
From the internal and external factors on the study, only broad money (M2) has a significant effect on profit-sharing of deposits in Islamic banks (Table 4). In the longterm, M2 has a positive effect. Conversely, in the short-term, M2 has a negative effect on profit-sharing of deposits in Islamic banks.

\section{Discussions}

\section{The effect of inflation on the profit-sharing of deposits and deposit rates}

Inflation does not affect the profit-sharing of deposits in Islamic banks, both long and short-term, while inflation has a positive long-term effect on conventional bank deposit rates. This research is supported by studies of Maulana (2017) and Effendi (2017) which stated that deposit rates respond positively to inflation. They stated that the ongoing inflation resulted in the increasing money supply in the economy, so banks raised their interest rates to attract the public making investment.

Inflation does not affect the profit-sharing of deposits; this finding is supported by Panorama's (2016) study which stated that savings do not affect inflation. In this condition, the withdrawal of Islamic banking savings funds is very possible in order to meet public consumption. Rare to overcome so that customers do not turn to conventional banks. So raising the profit-sharing rate makes the customer keep their money in Islamic banks.

High inflation is an economic problem causing the purchasing power (income) goes down. Individuals who earn a fixed income will be at a disadvantage while those who do not have a fixed income sometimes benefit. Thus, inflation can affect the income distribution. Inflation is the connecting variable between the interest rate and the effective exchange rate, where these two variables are important variables in determining growth in the production sector. Therefore, it is expected the role of the government to deal with rising inflation with the right policies immediately.

The central bank can carry out a discount policy by raising the interest rate. The goal is to encourage people to save money in the bank, so that both the money supply and the inflation rate can be reduced.

\section{The effect of the broad money on the profit-sharing of deposits and deposit rates.}

Broad money (M2) has a significant negative effect on the short-term and has a positive effect on long-term to deposit rates and profit-sharing of deposits. The finding of this research is similar to Panorama's (2016) study in which the money supply (M2) had a positive effect, meaning that if the money supply (M2) rises, it will result an increase in deposits. This finding is also supported by Sunaryati (2013), stating that the money supply had a negative and insignificant effect on the deposit sharing ratio.

\section{The effect of BI rate on the profit-sharing of deposits in Islamic banks and conventional bank deposit rates}

$\mathrm{BI}$ rate does not affect the profit-sharing of deposits in Islamic banks, both long and short-term, while the conventional bank deposit rates have a negative effect on the shortterm and have no significant effect on the long-term. It is also supported by Panorama (2016) which stated that the BI rate did not significantly affect deposits. The increase of $\mathrm{BI}$ rate as the companion interest rate on commercial banks, both directly and indirectly, will impact Islamic banks' performance. The increase in BI rate will affect the interest rate, which will also be followed by the increase in deposit rates and lending rates in conventional banks. The rise in deposit rates will make the public prefer to save their money on the conventional banks than on the Islamic banks. This concept is different 
from the Islamic banking system that uses a profit-sharing system on the use of funds by the borrower (either by the customer or the bank).

According to Prastowo's (2008) research, the increase in the BI rate had a positive and significant influence for banks by increasing deposit rates. This encouraged bank behavior in set deposit rates that follow the BI rate to maintain positive margins.

Banks want to maintain positive margins in interest rates funds and BI rate. The direction of monetary policy has not been fully responded by banks. This was reflected in continuing rises in deposit rates in the midst of the decline in the BI rate, among other things. This condition is expected to be a return on banking liquidity conditions.

\section{The effect of ROA on profit-sharing of Islamic bank deposits and interest on conventional bank deposits}

ROA does not affect the profit-sharing of Islamic banks deposits in the long and short-term. Furthermore, ROA also has no significant effect on deposits interest on conventional bank deposits, both in the long and short-term. Sudiyatno (2009) stated that ROA affected third-party funds. This condition would strengthen the perception of individuals to save their funds in the bank.

Effendi's research (2017) also supports the finding that ROA does not affect the profit-sharing of Islamic banks deposits. Deposits interest will decrease if ROA decreases because the profit or profitability of the bank is a bank's ability to make a profit. ROA shows a bank's ability to manage invested funds.

\section{The effect of OER on profit-sharing of Islamic bank deposits and interest on conventional bank deposits}

OER has a positive effect on the long-term and has a negative effect on short-term on conventional bank deposits interest while it does not affect the profit-sharing of Islamic banks deposits. This study supports the research of Wirawan (2016) that said OER had an effect on the deposits interest rate. In Islamic banks, this study supports the research of Andryani (2012) in which she stated that OER did not affect the profit-sharing of mudharabah deposits. Rahayu's research (2013) also stated that the OER variable did not affect the profit-sharing of deposits.

\section{CONCLUSIONS AND RECOMMENDATIONS}

\section{Conclusions}

Deposit rates respond to the variables of ROA, OER, BI rate, inflation, and M2. It means that in the short and long-term, the deposit interest strongly responds to OER, the smaller the OER ratio means the more efficient the operating expenses incurred by the bank concerned thus reducing the likelihood of a bank in troubled condition. The decreasing OER will also increase bank income as well as affect conventional bank deposit interest rates.

Deposit interest responds to the M2 which means that the short-term M2 will raise deposit interest rates that will affect and increase the broad money (M2) in the community. It is also to increase the level of liquidity, so banks compete to get the maximum funds from the community by raising deposit rates.

Deposit rates will respond if the BI rate increases and decreases this will affect the level of banking liquidity. During the period of inflation, people have more money. The $\mathrm{BI}$ rate will affect the level of bank liquidity, such as the banking policy in determining the deposit interest rate. An increase in the deposit interest rate will result in people saving their money in banks. The turmoil of external and internal variables greatly affects Islamic 
banks and conventional banks in determining interest and profit-sharing of deposits but it greatly affects conventional banks most.

\section{Recommendations}

In the context of the company's internal conditions, the company must increase efficiency in products, quality of human resources and technology level. The higher the level of these three aspects, the higher the return rate and the higher the level of trust in banks. It leads to high demand for investment in deposits and so forth.

External conditions are related to macroeconomic conditions, both social and political conditions. Government policies also influence investment decisions. Therefore, Bank Indonesia needs to keep taking a cautious stance in terms of prudential monetary and macro policies, taking into account of these external and internal factors.

\section{REFERENCES}

Andrianus, Fery, (2006), Analisis Faktor-Faktor Yang Mempengaruhi Inflasi Di Indonesia Periode 1997:3-2005:2. Economic Journal Of Emerging Markets,11(2),173-186

Andryani, K.I, \& Kunti, S. (2012) Analisis Pengaruh Return On Asset (ROA), BOPO, dan Suku Bunga Terhadap Tingkat Bagi Hasil Deposito Mudharabah Pada Bank Umum Syariah, Jurnal Ekonomi Bisnis, 11(01), 29-42

Antoni. (2015), The Dynamic Relationship Between Money Supply And Economic Growth, Department Of Economics, Economic Journal Of Emerging Markets, $7(2), 78-92$

Arif, R.A, \& M. Nur (2014), Spin-Off And Its Impact On The Third Party Funds Of Indonesian Islamic Banking Industry. Economic Journal Of Emerging Markets, $6(1), 50-55$

Dendawijaya, L. (2001). Manajemen Perbankan. Jakarta: Ghalia Indonesia

Effendi, J. (2017), The Determinant Of Equity Financing In Sharia Banking And Sharia Business Units, Economic Journal Of Emerging Markets, 10(1), 111-120

Ismail, (2011), Perbankan Syariah, Jakarta: Kencana Prenada Media Group

Iswardono, (1994), Uang Dan Bank, Yogyakarta: BPFE-Yogyakarta

Prastowo, N.J. (2008), Dampak BI Rate Terhadap Pasar Uang: Mengukur Signifikansi Respon Instrumen Pasar Keuangan Terhadap Kebijakan Moneter: Bank Indonesia, Working Paper 21, 1-60

Maulana, D. \& Fakhruddin. (2017), Analisis Hubungan Variabel Makro Dengan Penghimpunan Dana Pihak Ketiga Di Perbankan Umum, Jurnal Ilmiah Mahasiswa (JIM), 2(1), 227-238

Panorama, M. (2016), Pengaruh Pertumbuhan Ekonomi, Inflasi, Jumlah Uang Beredar (M2) dan BI rate Terhadap Tabungan Mudharabah Pada Perbankan Syriah Di Indonesia Periode 2005-2014: I-Economic,2(1), 102-121

Rahayu, S. (2013), Pengaruh Return On Asset, Bopo, Suku Bunga Dan Capital Adequacy Terhadap Tingkat Bagi Hasil Deposito Mudharabah Pada Perbankan Syariah: Jurnal Ilmiah Mahasiswa S1 Akuntansi Universitas Pandanaran,1(1), 1-16

Sriyana, J. (1995), Bagaimana Velositas Uang di Indonesia (Pendekatan Model Penyesuaian Parsial Berdasarkan Asumsi "Adaptive Expec tation" vs "Perfect Forsight" Economic Journal of Emerging Markets, 6,95-104

Sukirno, S. (2011), Makroekonomi Teori Pengantar, Jakarta: PT. Raja Grafindo Persada.

Subekti, I \& N.W. Widiyanti. (2004). "FaktorFaktor Yang Berpengaruh Terhadap Audit Delay di Indonesia", Simposium Nasional Akuntansi VII:991-1002.

Wirawan, A. (2016), Pengaruh ROA, ROE dan BOPO Terhadap Tingkat Bagi Hasil Deposito Mudharabah Pada Bank Umum Syariah, Sekolah Tinggi Ilmu Perbanas, Surabaya: Perbanas Institutional Repository, 12,1-18 